\title{
Pembuatan Mural untuk Menciptakan Suasana Edukatif dan Kreatif di RPTRA Mandala Tomang Jakarta
}

\author{
Andreana Lingga ${ }^{1}$, Jayanto Ginon Warjoyo ${ }^{2}$, Andreas Andreas ${ }^{3}$ \\ 1,2,3) Universitas Tarumanagara \\ andreanalingga06@gmail.com ${ }^{1}$,jayantog@fsrd.untar.ac.id ${ }^{2}$, andreas@fsrd.untar.ac.id ${ }^{3}$
}

\begin{abstract}
Abstrak- RPTRA (Ruang Terpadu Ramah Anak) merupakan salah satu program kerja pemprov DKI Jakarta. Sesuai dengan namanya, RPTRA harus menjadi pusat kegiatan warga sekitar yang ramah anak. Dalam tumbuh kembang anak, aspek kreativitas dan bermain menjadi sebuah metode belajar yang utuh. Kebutuhan tersebut perlu ddukung dalam sebuah metode yang terstruktur, untuk itu dirancanglah ilustrasi mural yang merepresentasikan imajinasi kreatif untuk membangun atmosfir pendidikan serta pembentukan karakter anak. Pengabdian kepada Masyarakat oleh dosen dalam lingkungan Universitas Tarumanagara sudah sewajarnya bermanfaat bagi lingkungan terdekat kampus. Karena itu dipilih RPTRA yang berdekatan dengan Untar, yaitu RPTRA Mandala di Kelurahan Tomang, Kecamatan Grogol Petamburan, Jakarta Barat.
\end{abstract}

Kata kunci: RPTRA Mandala; Mural; Imanjinasi; Eksplorasi; Ilustrasi

\section{PENDAHULUAN}

Pembangunan RPTRA merupakan kolaborasi dari berbagai pemangku kepentingan, yaitu Pemerintah Provinsi, Warga, pihak swasta, serta akademisi atau masyarakat sipil/madani. Kolaborasi keempat pemangku kepentingan yang disebut sebagai quadra-helix ini didasarkan pada tujuan untuk menciptakan masyarakat yang harmonis dalam sebuah kota yang ramah-anak. Hingga 2017 terdapat 186 buah RPTRA diresmikan, dengan tingkat kepuasan pengguna mencapai 99\% (Mungkasa, Oswar M, 2017).

RPTRA (Ruang Publik Terpadu Ramah Anak) Mandala di kelurahan Tomang, Kecamatan Grogol Petamburan, Jakarta Barat, memerlukan lingkungan yang kondusif secara visual dan estetika. Banyak anak-anak yang mempergunakan ruang publik ini untuk bermain, bereksplorasi serta berimajinasi. Dalam riset awal yang peneliti lakukan secara singkat, ruang publik ini pada hari biasa selalu ramai anak di sore hari. Mereka tidak hanya datang untuk bermain melepas penat sepulang sekolah, tapi mereka melakukan kegiatankegiatan non-akademis lainnya, misalnya: menari, menggambar, bermain sepak bola, membaca buku di perpustakaan, juga bermusik. Hal seperti ini merupakan kegiatan yang baik untuk proses tumbuh-kembang anak.

Membangun sebuah lingkungan yang kondusif secara visual dan estetika sangat diperlukan bagi anak-anak dalam membangun suasana belajar yang nyaman dan menyenangkan. Untuk itu stimulus atau rangsangan visual dapat berpengaruh positif terhadap kondisi psikologis dari masyarakat 
pengguna ruang publik ini. Seni mural adalah salah satu bentuk rangsang berupa media visual yang cocok untuk melengkapi ruang publik seperti RPTRA Mandala. Diharapkan dengan adanya pembuatan seni mural di RPTRA Mandala, dapat membantu membangun karakter, kreativitas, dan imajinasi anak, sekaligus semangat belajar. $\mathrm{Hal}$ ini didasarkan pada beberapa penelitian sebelum ini. Misalnya saja Sahala Simatupang (2017) mengutip beberapa penelitian lain, menyatakan bahwa ada proses sosial dalam suatu produksi ruang. Selain dari itu, Simatupang (2017) juga mengutip penelitian Nasongkhla dan Sintusingha, menyatakan bahwa produksi ruang bersifat dialektik antara hubungan ruang, waktu, dan sosial. Artinya produksi ruang tidak berada di ruang hampa dan seketika. Produksi ruang (terbuka) seperti RPTRA membutuhkan proses sosial, baik itu berupa proses top-down, instruksi Pemrprov kepada perusahaan untuk memberikan dana CSR (corporate social responsibility), serta proses masyarakat baik secara individu, maupun secara bersama melalui RT/RW, memaknai ruang tersebut. Faktor pemerintah sebagai kekuatan dominan, oleh Giddens, sebagaimana dikutip Simatupang (2017) disebut sebagai kekuatan pembentuk (structuring force) yang cukup menentukan, walau bukan satu-satunya. Dalam konteks itulah maka dialektika antara kekuatan pembentuk, dan warga pengguna ruang terbuka menjadi penting. Bahkan warga pun dapat ikut serta menjadi bagian dari kekuatan pembentuk itu, menggunakan berbagai metode dan medium. Ada beberapa variabel lain yang menjadi penting untuk disebut dalam proses pembentukan sikap di sebuah ruang terbuka, sebagaimana dijelaskan di bawah ini.

- Pendidikan dan Imajinasi: Memiliki imajinasi yang baik dapat membantu seseorang untuk memvisualkan dalam benak segala sesuatu yang sedang atau belum dilihat dan dialaminya. Dengan imajinasi yang baik ini seseorang dapat mengembangkan kreatifitas dan inovasi kedepannya.

- Ruang Publik: Ruang publik dapat diartikan sebagai tempat atau ruang yang dapat dimanfaatkan warga secara gratis dan bisa digunakan baik secara individual maupun berkelompok. Dengan adanya RPTRA akan membuat masyarakat sebuah kota lebih sehat dan gembira.

Keterkaitan antara ruang publik dan pengguna ruang publik khususnya kelompok usia anak dipengaruhi oleh banyak hal. Salah satunya adalah pengalaman bermain (yang menyenang kan), eksplorasi dan interaksi sensori 
dengan tempat. Hal ini diungkapkan oleh Susinety Prakoso dan Julia Dewi, bahwa "jika seorang anak secara berulang merasakan kesenangan dalam mengalami tempat, maka ikatan emosional akan terbentuk antara anak dan tempat" (Prakoso, Susinety, dan Julia Dewi, 2017). Karena itu menjadi penting menciptakan berbagai faktor yang mendukung terciptanya rasa senang saat anak sedang berada di RPTRA.

- Seni Urban sebagai manifestasi seni: Mural pada dasarnya adalah sebuah medium yang memiliki fungsi komunikasi, bukan kesenian murni sebagai media ekspresi dari seniman. Mural pertama yang diciptakan manusia adalah lukisan di dinding gua prasejarah, yang dibuat sebagai media edukasi dan media upacara (Tabrani, 2005).

Pada masa Seni Kristen Awal hingga Abad Pertengahan, seni lukis di dinding digunakan sebagai sarana ibadah, menggambar di dinding kuburan (catacombe) dan dinding Gereja. Pada masa modern abad 20 mural banyak digunakan sebagai media komunikasi yang lebih bersifat ideologis dan sosial-politis.. Diego Rivera (1886-1957) adalah salah-satu seniman mural ternama asal Mexico yang ternama, yang menggunakan mural sebagai media perjuangan dan propaganda.

Di masa kini seni mural selain sebagai media komunikasi juga sebagai sebuah karya seni yang bersifat egaliter, dapat dinikmati oleh siapapun, tak terikat pada galeri sebagai salah satu medan seni. Seni mural memang pada dasarnya adalah media komunikasi yang bersifat edukatif, atau sekedar menimbulkan kesan keindahan bagi pelihatnya.

Satu hal yang dapat disimpulkan dari terbentuknya kesenian urban, yakni dalam berkreativitas tidakt memiliki Batasan media. Lingkup urban atau perkotaan adalah konteks, yang mencakup semua aspek kehidupan dan bergerak secara dinamis. Seni urban telah membuktikan bahwa minimnya ruang dan banyaknya problematika kota urban tidak menjadi halangan untuk berekspresi.

- Mural: seni mural dapat digunakan sebagai salah satu instrumen komunikasi publik dalam ruang masyarakat. Penggunaan seni mural untuk komunikasi publik akan memperlancar jalannya penguatan masyarakat. Hal ini disebabkan karena selain sebagai karya seni yang mengekspresikan realitas sosial-politik sehari-hari ataupun ekspresi dari imajinasi, 
mural juga menjadi rujukan secara sosial bagi warga yang melihatnya. Warga yang melihat mural diharapkan dapat menikmati dan paham maksud dari mural, untuk kemudian sedikit-banyak dapat mempengaruhi sikap dan pemikirannya.

\section{METODE}

Penelitian ini lebih merupakan upaya perekaman proses kreatif dalam pembuatan mural, sebagai upaya pemecahan masalah terhadap keadaan di lingkungan sekitar. Adapun manfaat dan kegunaan dari mural terhadap lingkungan, membutuhkan satu penelitian tersendiri.

Metode yang digunakan adalah metode kualitatif, mengumpulkan dan bekerja dengan data non-numerik dan yang berupaya menafsirkan makna dari data ini, sehingga membantu kita memahami kehidupan sosial melalui studi populasi atau tempat yang ditargetkan. Metode riset ini lebih bersifat memberikan gambaran secara jelas suatu permasalahan sesuai dengan fakta di lapangan.

Berikut adalah tahapan-tahapannya:

\section{Observasi dan identifikasi permasalahan:}

Saat peneliti meninjau lokasi ke RPTRA Mandala peneliti menemukan permasalahan bawa ruang publik ini kurang adanya unsur kreatif yang berguna untuk membangun atmosfer pendidikan dan karater anak

\section{Merumuskan pertanyaan riset:}

Melakukan riset awal dengan merespon permasalahan yang ada di RPTRA Mandala, dan membandingkannya dengan ruang publik lain di kota urban. Mengumpulkan beberapa pertanyaan yang akan diolah dan dikembangkan pada proses selanjutnya.

3. Mengumpulkan dan menganalisis data: Perkenalan dengan pihak RPTRA Mandala, mencari data dan menjajaki kebuthan RPTRA Mandala. Mininjau dan mendapat data teknis lokasi mural.

4. Menjawab pertanyaan dengan mengeksekusi hasil berupa mural: Mempresentasikan rencana pelaksanaan mural dan tema mural, koordinasi dengan tim pembuat maupun pengurus RPTRA Mandala, hingga pelaksanaan pembuatan mural di RPTRA Mandala.

Proses ini sangat penting mengingat, pada tahap ini dirancang komposisi, bentuk, dan warna mural agar sesuai dengan tema yang ditentukan. Kata kunci dari mural ini adalah kreativitas dan ilmu pengetahuan. Diharapkan mural dapat merepresentasikan semangat keilmuan dan kebudayaan 
Nusantara yang beragam, serta juga kreativitas, dengan tampilan yang menghibur dan menyenangkan.

Gaya yang dipilih bersifat campuran antara obyek yang bersifat nyata dengan penggayaan dalam bentuk datar (flat) dua dimensional. Untuk latar belakang digunakan bidang-bidang warna-warni untuk merepresentasikan suasana menyenangkan, selain juga keberagaman budaya Nusantara.

Obyek-obyek yang dipilih untuk merepresentasikan ilmu pengetahuan misalnya, pesawat terbang, pesawat luar angkasa, ilmuwan dan mikroskopnya. Demikian pula dengan kekayaan alam dan keindahannya, seperti adanya planet, bintang, pegunungan yang indah. Adapun obyek untuk merepresentasikan budaya, misalnya topeng Barong Rangda Bali, tokoh wayang Gatot kaca sedang terbang.

Kreativitas direpresentasikan dengan kegembiraan dalam bermain, dan tangga tinggi yang menjulang ke angkasa. Demikian pula dengan unsur penuh warna yang menjadi latar belakang mural.

Dari segi Bahasa gambar, pembuatan mural menggabungkan du acara gambar, yaitu bahasa gambar 'Timur' dan Bahasa gambar khas 'Barat', sebagaimana diungkapkan oleh pakar Bahasa gambar Primadi Tabrani. Komposisi keseluruhan dari mural ini bertumpuk ke atas, mencampurbaurkan berbagai ruang yang berjauhan bertumpuk menjadi satu. Artinya komposisi mural tidak bersifat nyata dan bukan cara penggambaran perspektivis ruang-waktu datar (RWD) atau naturalistic-perspective-moment opname (NPM) yang bersifat rasional, sesuai dengan prinsip gambar perspektif yang dikembangkan dalam budaya gambar masyarakat Eropa-Amerika. Namun dalam penampilan keseluruhan mural ini tidak mengandung dimensi waktu. Dengan kata lain merekam keadaan secara still-picture atau gambardiam, membekukan momentum (Tabrani, 2005).

Secara keseluruhan mural, diharapkan penggabungan berbagai obyek dalam ruang beragam, misalnya luar angkasa, pegunungan, taman, dalam satu bidang gambar yang penuh warna, diharapkan dapat mengembangkan imajinasi anak/remaja pengunjung RPTRA. Demikian pula obyek-obyek yang dipilih dalam mural, yang merepresentasikan ilmu pengetahuan dan kebudayaan, diharapkan juga 
dapat membangun semangat belajar dengan cara yang menyenangkan.

\section{HASIL DAN PEMBAHASAN}

Pembuatan mural dilakukan oleh 20 orang, yaitu 16 mahasiswa dan empat dosen. Lama pengerjaan delapan jam, dibagi tiga sesi:

- Sesi 1 : Pengerjaan outline obyek utama dan pendukung

- Sesi 2 : Pengerjaan bidang obyek utama dan pendukung

- Sesi 3: Pengerjaan latar belakang, depan dan penyelesaian akhir.

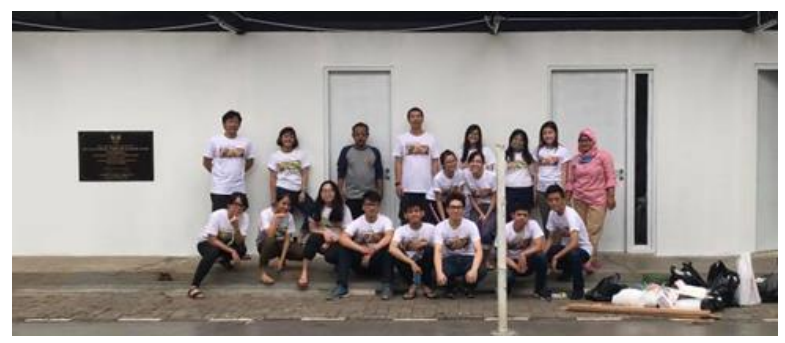

Gambar 1. Sebelum pelaksanaan membuat mural. (Sumber: Pribadi)

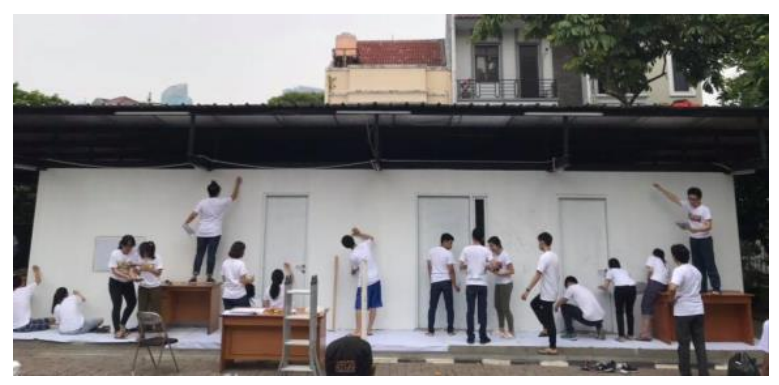

Gambar 2. Pembuatan sketsa dengan metode skala menggunakan grid dan outline.

(Sumber: Pribadi)

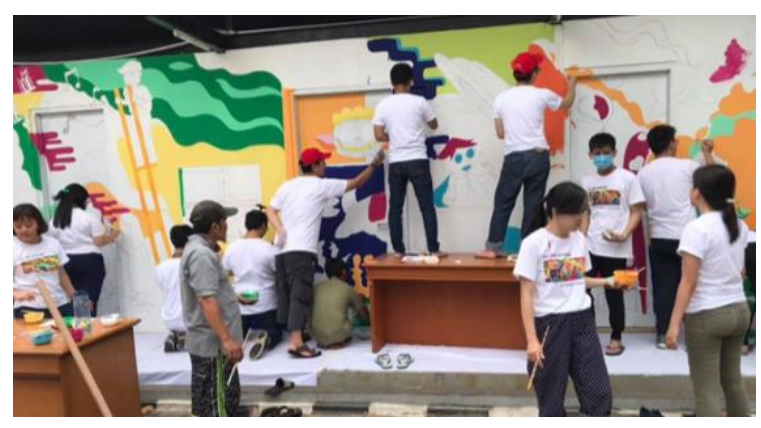

Gambar 3. Pemberian block dan warna-warna dasar. (Sumber: Pribadi)

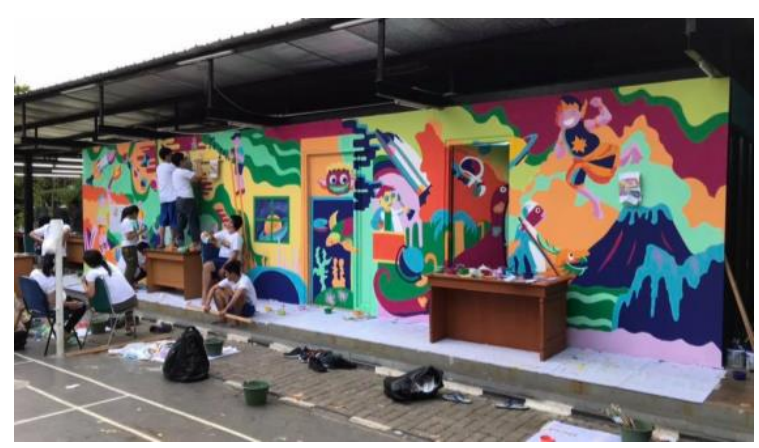

Gambar 4. Finishing mural (Sumber: Pribadi)

Hasil dari kegiatan ini terdiri dari dua hal yang sangat berharga, yaitu hasil takbenda (intangible output) dan hasil bendawi (tangible output). Sebagaimana sebuah proses pendidikan, hasilnya dapat berupa pembentukan karakter dan pengembangan skill atau kompetensi, selain juga hasil berupa karyakarya penelitian dan penciptaan.

Hasil abstrak berupa program kegiatan yang bersifat edukatif. Disebut Edukatif karena mahasiwa yang dilibatkan selain belajar secara estetika dan fungsional terkait melukis mural, juga belajar bahwa seni rupa dan desain memiliki tanggung jawab sosial dan moral bagi lingkungannya. 
Hasil dari kegiatan melukis mural yang bersifat intangible adalah pengalaman berkarya seni publik di ruang terbuka di luar kampus bagi para mahasiswa. Manfaat langsung bagi pembuat mural bukan mahasiswa adalah, pengalaman langsung berkarya seni sehingga diharapkan rasa memiliki warga terhadap RPTRA meningkat. Bagi Petugas PPSU (Pelaksanaan Prasarana dan Sarana Umum) yang terlibat, akan percaya diri untuk memperbaiki mural tersebut. Diharapkan juga para pihak yang terlibat akan bersemangat untuk membuat mural yang berbeda di bagian lain dari RPTRA Mandala. Hasil berupa semangat dan pengalaman dari tiap individu yang terlibat dalam kegiatan melukis mural secara bersama-sama adalah sebuah luaran intangible yang sangat berarti. Hasil kedua adalah jenis hasil yang bersifat tangible atau nyata, yaitu berupa sebuah lukisan mural di salah satu dinding RPTRA Mandala, berukuran $12 \times 2,5$ meter.

\section{SIMPULAN}

Masyarakat membutuhkan ruang bersama untuk melepaskan diri dari rutinitas dan kejenuhan kerja. Demikian pula dengan anakanak, mereka membutuhkan sarana maupun kegiatan untuk bermain anak. Ruang publik seperti RPTRA Mandala menyediakan medium komunikasi bagi warga untuk berinteraksi ke sesama serta menjadi medium untuk berekspresi dan berkomunikasi dalam bentuk karya seni mural. RPTRA yang memiliki suasana (ambience) ceria dan imajinatif akan lebih menyenangkan untuk pengguna RPTRA, khususnya anak-anak.

Kegiatan mural ini tidak hanya dilakukan oleh tim dosen bersama mahasiswa FSRD Universitas Tarumanagara saja, namun masyarakat sekitar dengan antusias turut serta dalam kegiatan mural baik anak-anak hingga dewasa. Kegiatan mural tersebut di atas tidak hanya membangun suasana yang kondusif secara visual dan estetika, namun juga suasana kreatif bagi masyarakat sekitar pada umumnya, dan anak-anak khususnya.

Karya mural pada ruang publik RPTRA Mandala ini telah menghidupkan atmosfer postif pada kegiatan-kegiatan yang ada di sana. Oleh sebab itu sebagai penutup, disarankan untuk memperbanyak kegiatan pengabdian kepada masyarakat serupa ke RPTRA-RPTRA lain di kelurahan-kelurahan sekitar kampus Untar agar terbangun atmosfer kreatif dan positif bagi warga.

\section{UCAPAN TERIMA KASIH}

Terima kasih kepada pihak-pihak yang telah membantu terselenggaranya kegiatan pembuatan mural di RPTRA Mandala, kelurahan Tomang, yaitu: 
- Bapak Nurhamim selaku koordinator beserta anggota pengurus RPTRA Mandala, dan para petugas PPSU.

- Warga di sekitar RPTRA Mandala, Tomang. Baik yang ikut terlibat langsung melukis mural, maupun secara tidak langsung mendukung.

- Mahasiswa DKV FSRD Tarumanagara yang telah membantu pembuatan mural ini dengan penuh semangat, tak kenal lelah.

\section{DAFTAR PUSTAKA}

Barton, Will, dan Beck, Andrew. 2010. Bersiap Mempelajari Kajian Komunikasi, Yogyakarta: Jalasutera.

Campbell, Scott and Fainstein, Susan S. 1996.

Reading in Planning Theory. Cambridge. Blackwell Publishers.

Lawson, Bryan.1980. Bagaimana Cara Berpikir Desainer (How Designers Think), Yogyakarta \& Bandung: Jalansutra

M.,Yusuf, Pawit. 2010. Komunikasi Intruksional; Teori dan Praktik. Jakarta: Bumi Aksara
Mungkasa, Oswar M., 2017, Ruang Publik Terpadu Ramah Anak (RPTRA), Konsep, Implementasi, dan Pembelajaran, FGD Penyediaan Ruang Terbuka Hijau (RTH), yang Responsif Gender dan Ramah Anak, Kementerian Pemberdayaan Perempuan dan Perlindungan Anak, 18 Agustus 2017.

Prakoso, Susinety, Julia Dewi, (2017, 1 januari, Vol 17, No.1) NALARs Jurnal Arsitektur Universitas Pelita Harapan, 1-10.

Rohidi, Tjetjep Rohendi. 2011. Metode Penelitian Seni. Jakarta: Cipta Prima Nusantara.

Simatupang, Sahala, 2017. Proses Sosial dalam Produksi Ruang Publik RPTRA Kalijodo di Jakarta, (Jurnal Scale, Vol 5, No.1, Agustus 2017) , Jakarta, 44-45.

Soedarso, SP. 1990. Tinjauan Seni Sebuah Pengantar untuk Apresiasi Seni. Yogyakarta: Saku Dayar Sana.

Tabrani, Primadi, 2009, Bahasa Rupa, Bandung: Penerbit Kelir. 